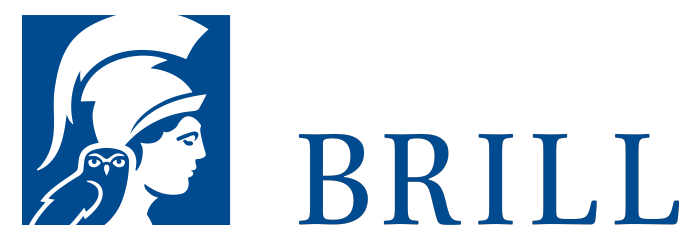

\title{
Sociolinguistics of the Luvian Language
}

Author: Ilya Yakubovich

Luvian is the language of Anatolian hieroglyphic inscriptions and a close relative of Hittite. This book explores the Luvian ethnic history through sociolinguistic methods, with an emphasis on the interpretation of contacts between Luvian and its linguistic neighbors, such as Hittite, Hurrian, and Greek. It is concluded that Luvian was originally spoken in the central part of Anatolia. Subsequent Luvian migrations were connected with the expansion of the Hittite state, where Hittite was the socially dominant language, but the Luvian speakers were more numerous. The unstable balance between the Hittite and the Luvian speakers continued to shift in favor of the second group, to the point that the Hittite elites were fully bilingual in Luvian.

Readership

Hittitologists, Indo-Europeanists, historians of ancient Anatolia, specialists in language contact.

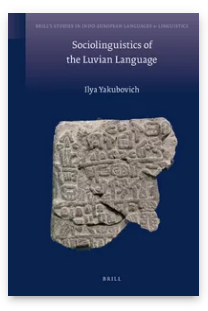

Pages: xvi, 456 pp.

Language:

English

Subjects: Indo-

European

Languages,

Languages and

Linguistics,

Linguistics,

Ancient Near

East and Egypt,

Sociolinguistics,

Languages and

Linguistics,

Multilingualism

\& Language

Contact,

Languages and

Linguistics

Publisher: Brill

Series:

Brill's Studies in

Indo-European

Languages \&

Linguistics,

Volume: 2

E-Book (PDF)

Released online:

15 Nov 2009

ISBN: 978-90-

47-44027-7

Hardback 
Ilya Yakubovich is a recent graduate of the Joint Ph.D. Program ISBN: $978-90-$ in Linguistics and Near Eastern Studies of the University of Chicago. His research interests include language contact, sociohistorical and Indo-European linguistics, Anatolian and Iranian philology.

For more information see brill.com

Order information: Order online at brill.com +44330 333 o049 | customerservices@brill.com Submission information: brill.com/authors

Titles published by Brill | Fink, Brill | mentis or Brill | Schöningh: +49(o)71 5413279216 | brill@brocom.de 